\title{
ANALISIS USAHA MINYAK KELAPA DI KECAMATAN ENOK KABUPATEN INDRAGIRI HILIR
}

\author{
Rita Ramadayanti, Partini Partini \\ Program Studi Agribisnis Universitas Islam Indragiri \\ Email: green_tien2@yahoo.com
}

\begin{abstract}
ABSTRAK
Kelapa merupakan tanaman perkebunan utama yang dibudidayakan oleh petani di Kabupaten Indragiri Hilir dengan luasan mencapai 440.821 hektar. Salah satu produk turunan kelapa yang diusahakan oleh masyarakat terutama ibu rumah tangga di Kecamatan Enok adalah minyak kelapa. Penelitian ini bertujuan (1) Untuk mengetahui biaya total, penerimaan dan keuntungan usaha minyak kelapa yang ada di Kecamatan Enok Kabupaten Indragiri Hilir, (2) Untuk mengetahui efisiensi usaha minyak kelapa yang ada di Kecamatan Enok Kabupaten Indragiri Hilir, (3) Untuk mengetahui besarnya nilai tambah usaha minyak kelapa di Kecamatan Enok Kabupaten Indragiri Hilir. Metode penelitian dengan cara sensus yaitu seluruh pengusaha minyak kelapa sebanyak 10 orang sebagai sampel penelitian. Hasil penelitian menunjukkan bahwa (1) Biaya total pada usaha minyak kelapa di Kecamatan Enok sebesar Rp. 65.862,00 per produksi, penerimaan sebesar Rp. 131.575,00 per produksi dan keuntungan sebesar Rp. 64.862,33 per produksi, (2) Nilai Efisiensi atau R/C sebesar Rp. 1,96 artinya usahatani minyak kelapa efisien bagi pengusaha di Kecamatan Enok, (3) Nilai tambah kelapa bulat menjadi minyak kelapa sebesar Rp. $1.535,17$ per kg.
\end{abstract}

Kata kunci : Minyak kelapa, efisiensi, nilai tambah.

\section{ABSTRACT}

Ccoconut is main plantation commodity of farmer in District of Indragiri Hilir with large 440.821 hectare. One of derivate product is coconut oil. The purposes of this study were (1) To know the cost, revenue and profit of coconut oil business in subdistrict of Enok district of Indragiri Hilir, (2) to know efficiency of coconut oil business in subdistrict of Enok district of Indragiri Hilir, (3) to know the value added of coconut oil business in subdistrict of Enok district of Indragiri Hilir. The method of research was cencus, involving 10 samples. The results of research showed that (1) total cost of coconut oil business in Subdistrict of Enok is 65.862,00 per production, total revenue $R$ p. $131.575,00$ per production and profit $R p$. 64.862,33 per production; (2) $R C$ ratio 1,96, it meant that coconut oil business was efficient; (3) Value added of processing coconut to coconut oil Rp. $1.535,17$ per $\mathrm{kg}$.

Keywords:Coconut oil, efficiency, value added.

\section{PENDAHULUAN}

Kabupaten Indragiri Hilir memiliki produksi kelapa yang terbesar di Provinsi Riau, dengan luasan mencapai 440.821 hektar dan diusahakan oleh 80.264 petani (Badan Pusat Statistik Indragiri Hilir, 2015) . Berkebun kelapa merupakan mata pencaharian yang diandalkan oleh masyarakat, namun harga jualnya berfluktuasi, sangat berpengaruh terhadap perekonomian masyarakat secara keseluruhan.

Tingginya produksi kelapa mendorong masyarakat untuk mengolahnya menjadi berbagai produk 
turunan. Produk turunan kelapa yang telah dikembangkan, meliputi kopra, gula kelapa, santan kelapa, arang tempurung, virgin coconut oil, minyak kelapa. Produk turunan kelapa yang telah dikembangkan merupakan usaha untuk meningkatkan pendapatan petani, bahkan dengan menghasilkan produk turunan kelapa pendapatannya akan jauh lebih baik dibandingkan dengan menjual kelapa segar, bila harga kelapa bulat sedang merosot dipasaran.

Salah satu produk turunan kelapa yang diusahakan oleh masyarkat terutama ibu rumah tangga di Kecamatan Enok adalah minyak kelapa. Walaupun peran minyak kelapa sudah tergeser oleh minyak sawit tetapi masih usaha rumah tangga ini masih berjalan di Kecamatan Enok. Minyak kelapa merupakan bagian paling berharga dari buah kelapa. Minyak kelapa sering dipergunakan sebagai bahan baku industri dan pembuatan minyak goreng. Selain itu, minyak kelapa baik digunakan untuk meningkatkan kesehatan masyarakat.

Usaha pembuatan minyak kelapa ini telah ada secara turun-temurun dan masih bersifat tradisional, baik dalam proses produksi maupun pemasarannya. Walaupun berskala rumah tangga dan masih bersifat tradisonal. Berdasarkan dari Dinas Koperasi dan UMKM Kabupaten Indragiri Hilir tahun 2017 terdapat 28 orang yang mengusahakan pembuatan minyak kelapa. Namun saat ini, jumlah pengusaha minyak kelapa yang masih aktif hanya berjumlah 10 orang.

Berdasarkan latar belakang di atas maka tujuan dari penelitian ini adalah :

1. Untuk mengetahui biaya total, penerimaan dan keuntungan usaha minyak kelapa yang ada di Kecamatan Enok Kabupaten Indragiri Hilir.
2. Untuk mengetahui efisiensi usaha minyak kelapa yang ada di Kecamatan Enok Kabupaten Indragiri Hilir.

3. Untuk mengetahui besarnya nilai tambah usaha minyak kelapa yang ada di Kecamatan Enok Kabupaten Indragiri Hilir.

\section{METODOLOGI PENELITIAN}

\subsection{Waktu dan Tempat Penelitian}

Penelitian ini dilakukan di Kecamatan Enok Kabupaten Indragiri Hilir. Penentuan lokasi penelitian ini dipilih secara sensus dari data Dinas Koperasi dan UMKM Kabupaten Indragiri Hilir, 2017 dengan beberapa pertimbangan bahwa wilayah tersebut memiliki banyak pelaku usaha pengolahan minyak kelapa. Pelaksanaan penelitian ini dilakukan pada periode Desember 2019 hingga periode Februari 2020.

\subsection{Jenis dan Sumber Data}

Sumber data yang diperlukan pada penelitian ini adalah:

1. Data Primer diperoleh langsung dari responden melalui wawancara dengan menggunakan daftar pertanyaan (kuisioner) yang sudah disiapkan. Sumber data primer dari penelitian ini adalah pelaku usaha minyak kelapa di Kecamatan Enok Kabupaten Indragiri Hilir. Data yang diambil seperti biaya produksi usaha minyak kelapa, harga jual, jumlah penjualan.

2. Data Sekunder diperoleh dari instansi (lembaga) yang terkait diantaranya berasal dari Badan Pusat Statistik, data Dinas Koperasi dan UKM Kabupaten Indragiri Hilir, 2017.

\subsection{Metode Penetapan Sampel}

Metode pengambilan sampel dilakukan dengan sensus. Populasi 
dalam penelitian ini adalah pelaku usaha agroindustri minyak kelapa yang berproduksi di Kecamatan Enok Kabupaten Indragiri Hilir. Jumlah pengusaha minyak kelapa yang aktif sampai saat ini berjumlah 10 orang. Dari 10 orang tersebut, seluruhnya dijadikan sebagai sampel penelitian.

\subsection{Metode Analisis Data}

Untuk mengetahui total biaya produksi secara sistematis dirumuskan sebagai berikut :

\section{Biaya Total}

$$
\mathrm{TC}=\mathrm{FC}+\mathrm{VC}
$$

Dimana :

$$
\begin{array}{ll}
\text { TC } & \text { = Biaya Total }(\mathrm{Rp} / \text { Produksi }) \\
\text { FC } & =\text { Biaya Tetap }(\mathrm{Rp} / \text { Produksi }) \\
\text { VC } & =\text { Biaya Variabel }(\mathrm{Rp} / \text { Produksi) }
\end{array}
$$

\section{Penyusutan Alat}

Untuk menghitung biaya penyusutan alat dalam usaha tani dihitung dengan metode garis lurus menurut Sinuraya (1985). Dengan rumus sebagai berikut:

$$
D=\frac{C-S V}{U L}
$$

Dimana :

D = Nilai penyusustan alat

C = Harga beli alat

SV = Nilai sisa $(20 \% \times$ nilai beli $)$

$\mathrm{UL}=$ Masa pakai

\section{Analisis Penerimaan}

Penerimaan adalah perkalian antara produksi yang dihasilkan dengan harga jual dan biasanya produksi berhubungan negatif dengan harga, artinya harga akan turun ketika produksi berlebihan (Soekartawi, 1995). Penerimaan dapat dihitung dengan menggunakan rumus sebagai berikut :

$$
\mathrm{TR}=\mathrm{Q} \times \mathrm{P}
$$

Keterangan :

$$
\begin{aligned}
& \mathrm{TR}=\text { Penerimaan Total }(\mathrm{Rp} / \text { Produksi) } \\
& \mathrm{Q}=\operatorname{Jumlah}(\mathrm{Kg} / \text { Produksi) } \\
& \mathrm{P} \quad=\text { Harga }(\mathrm{Rp} / \text { Produksi })
\end{aligned}
$$

\section{Keuntungan}

Keuntungan (Pendapatan bersih) adalah selisih lebih pendapatan atas beban sehubungan dengan usaha untuk memperoleh pendapatan tersebut selama periode tertentu. Dapat ditulis dengan rumus sebagai berikut :

$$
\pi=\mathrm{TR}-\mathrm{TC}
$$

Dimana:

$$
\begin{aligned}
& \pi=\text { Pendapatan Bersih (Rp/Produksi) } \\
& \text { TR }=\text { Penerimaan Total (Rp/Produksi) } \\
& \text { TC }=\text { Biaya Total (Rp/Produksi) },
\end{aligned}
$$

\section{Pendapatan Kerja Keluarga}

Menurut Hernanto (1991), untuk menghitung pendapatan keluarga digunakan rumus sebagai berikut:

Keterangan :

$$
\mathrm{PKK}=\pi+\mathrm{TKDK}+\mathrm{D}
$$

$$
\begin{aligned}
\mathrm{PKK}= & \text { Pendapatan kerja keluarga } \\
& (\text { Rp/Produksi) } \\
\pi \quad & \text { Keuntungan (Rp/Produksi) } \\
\mathrm{TKDK}= & \text { Upah tenaga kerja dalam } \\
& \text { keluarga (Rp/Produksi) } \\
\mathrm{D} \quad= & \text { Penyusutan alat (Rp/Produksi) }
\end{aligned}
$$

\section{Efisiensi}

Menurut Soekartawi (2002), analisis Return Cost (R/C) ratio merupakan perbandingan (ratio atau nisbah) antara penerimaan (revenue) dan biaya (cost), yang dikeluarkan dalam satu kali produksi. untuk mengetahui efisiensi, maka rumus yang dipakai yaitu:

$$
\mathrm{R} / \mathrm{C}=\mathrm{TR} / \mathrm{TC}
$$

dimana:

$\begin{aligned} \mathrm{TR} & =\text { Penerimaan total }(\mathrm{Rp}) \\ \mathrm{TC} & =\text { Total biaya }(\mathrm{Rp})\end{aligned}$ 
Kriteria yang digunakan dalam penilaian efisiensi usaha adalah :

- $\quad \mathrm{R} / \mathrm{C}$ Ratio > 1, Usaha dinyatakan layak.

- $\quad \mathrm{R} / \mathrm{C}$ Ratio = 1, Usaha dinyatakan berada pada titik impas.
- $\quad \mathrm{R} / \mathrm{C}$ Ratio $<1$, Usaha pengolahan minyak kelapa tidak layak.

Analisi Nilai Tambah

Perhitungan nilai tambah digunakan metode hayami, yang dihitung menggunakan tabel 1.

Tabel 1. Metode Perhitungan Analisis Usaha dan Nilai Tambah Produk Minyak Kelapa dengan Metode Hayami.

\begin{tabular}{lcl}
\hline \multicolumn{1}{c}{ Variabel } & Nilai & \multicolumn{1}{c}{ Cara Perhitungan } \\
\hline Output, Input dan Harga & & \\
- Hasil produksi (liter) & 1 & \\
- Bahan baku (kg) & 2 & \\
- Tenaga kerja (orang) & 3 & \\
- Faktor konversi & 4 & $=1 / 2$ \\
- Koefisien tenaga kerja & 5 & $=3 / 2$ \\
- Harga bahan baku (Rp/kg) & 6 & \\
- Upah tenaga kerja (Rp/orang) & 7 & \\
Penerimaan dan Keuntungan & & \\
- Harga kelapa (Rp/kg) & 8 & \\
- Sumbangan input lain (Rp/kg) & 9 & \\
- Nilai produk $(\mathrm{Rp} / \mathrm{kg})$ & 10 & $=4 \times 6$ \\
- Nilai tambah $(\mathrm{Rp} / \mathrm{kg})$ & $11 \mathrm{a}$ & $=10-9-8$ \\
- Rasio nilai tambah $(\mathrm{Rp} / \mathrm{kg})$ & $11 \mathrm{~b}$ & $=(11 \mathrm{a} / 10) \times 100 \%$ \\
- Imbalan tenaga $\mathrm{kerja}(\mathrm{Rp} / \mathrm{kg})$ & $12 \mathrm{a}$ & $=5 \times 7$ \\
- Pangsa tenaga $\mathrm{kerja}(\%)$ & $12 \mathrm{~b}$ & $=(12 \mathrm{a} / 11 \mathrm{a}) \times 100 \%$ \\
- Keuntungan $(\mathrm{Rp} / \mathrm{kg})$ & $13 \mathrm{a}$ & $=11 \mathrm{a}-12 \mathrm{a}$ \\
- Tingkat keuntungan $(\mathrm{Rp} / \mathrm{kg})$ & $13 \mathrm{~b}$ & $=(13 \mathrm{a} / 11 \mathrm{a}) \times 100 \%$ \\
\hline
\end{tabular}

\section{HASIL DAN PEMBAHASAN}

\subsection{Karakteristik Responden} Umur

Umur akan mempengaruhi kemampuan fisik seseorang terhadap melakukan pekerjaan. Soekortawi (1995) menyata dari segi umur petani yang berumur lebih muda akan lebih berani menghadapi resiko dan lebih cepat dalam menerima informasi dan teknologi baru.

Tabel 2. Karateristik Responden

Berdasarkan Umur

\begin{tabular}{cccc}
\hline No & $\begin{array}{c}\text { Umur } \\
\text { (tahun) }\end{array}$ & $\begin{array}{c}\text { Jumlah } \\
\text { (orang) }\end{array}$ & $\begin{array}{c}\text { Persentase } \\
(\%)\end{array}$ \\
\hline 1. & $21-30$ & 1 & 10,00 \\
2. & $31-40$ & 4 & 40,00 \\
3. & $41-50$ & 5 & 50,00 \\
\hline & Jumlah & 10 & 100,00
\end{tabular}

Sumber: Data primer diolah, 2020

Berdasarkan pada tabel 2 dapat dilihat bahwa umur responden yang terbanyak adalah umur 41 hingga 50 tahun yaitu sebanyak 5 orang, umur 21 hingga 30 yaitu sebanyak 1 orang dan umur 31 hingga 40 yaitu sebanyak 4 orang. Hal ini menunjukkan umur responden didaerah penelitian mayoritas tergolong kedalam usia produktif.

\section{Tingkat Pendidikan}

Pendidikan sangat mempengaruhi sikap dan daya fikir seseorang terutama dalam menerima inovasi baru untuk menjalankan suatu usaha agar memperoleh hasil yang lebih baik dengan memanfaatkan pendidikan yang dimiliki baik formal maupun informal. 
Tingkat pendidikan mempunyai pengaruh bagi pengusaha dalam melaksanakan kegiatan usahanya, terutama terhadap cara pengelolaannya. Kemampuan mengelola yang baik disebabkan karena wawasan dan pengetahuan yang dimiliki semakin banyak dan luas serta semakin terbuka terhadap inovasi yang dianjurkan.

Tabel 3. Kareteristik

Responden

Berdasarkan Tingkat Pendidikan.

\begin{tabular}{clcc}
\hline No & $\begin{array}{c}\text { Tingkat } \\
\text { pendidikan }\end{array}$ & $\begin{array}{c}\text { Jumlah } \\
\text { (orang) }\end{array}$ & $\begin{array}{c}\text { Persentase } \\
(\%)\end{array}$ \\
\hline 1. & SD & 7 & 70,00 \\
2. & SLTP & 2 & 20,00 \\
3. & SLTA & 1 & 10,00 \\
& Jumlah & 10 & 100,00 \\
\hline
\end{tabular}

Sumber: Data primer diolah, 2020

Berdasarkan pada tabel 3 dapat diihat bahwa tingkat pendidikan responden yang paling banyak adalah pada tingkat SD yaitu sebanyak 7 orang atau sebesar 70,00 persen. Hal ini menunjukkan bahwa tingkat pendidikan responden di daerah penelitian tergolong rendah dan perlu peningkatan pengetahuan baik secara pendidikan formal maupun non formal.

\section{Pengalaman Usaha}

Usaha minyak kelapa di Kecamatan Enok sudah berlangsung lama. Sebelum minyak sawit popular, masyarakat biasa menggunakan minyak kelapa untuk memasak. Pengalaman usaha responden yang terbanyak adalah pengalaman usaha 11 hingga 20 yaitu sebesar 80,00 pesen dan pengalam usaha 1 hingga 10 yaitu sebesar 20,00 persen. Pengalaman ini bisa diperoleh berdasarkan pola pengasuh orang tua yang berprofesi wirausaha, atau dari pengalaman mengelola usaha sebelumnya.

Tabel 4. Karakteristik Responden Berdasarkan Pengalaman Usaha.

\begin{tabular}{cccc}
\hline No & $\begin{array}{c}\text { Pengalaman } \\
\text { Usaha }\end{array}$ & $\begin{array}{c}\text { Jumlah } \\
\text { (orang) }\end{array}$ & $\begin{array}{c}\text { Persentase } \\
(\%)\end{array}$ \\
\hline 1. & $1-10$ & 2 & 20,00 \\
2. & $11-20$ & 8 & 80,00 \\
& Jumlah & 10 & 100,00 \\
\hline
\end{tabular}

Sumber: Data primer diolah, 2020

\subsection{Proses Pembuatan Minyak Kelapa \\ Proses pembuatan minyak} kelapa memerlukan waktu dua hari mulai dari pembelahan sampai produk jadi, meliputi tahapan sebagai berikut :

1. Daging buah diparut kemudian diberi air hangat lalu diperas dan disaring sehingga diperoleh santan.

2. Santan didiamkan selama semalam. Saat proses pendiaman ini diberikan sedikit garam dengan ukuran satu sendok. Pemberian garam berfungsi untuk membantu proses pemisahan antara santan dan air.

3. Santan dan air yang terpisah, lalu pilih santannya saja

4. Selanjutnya santan dimasak. Selama proses pemasakan, santan diaduk secara perlahan-lahan dan terusmenerus. Saat santan dalam proses pemasakan masukkan dua helai daun pandan wangi dan satu buah cabe merah kering kedalam nya. Daun pandan wanggi dan cabe merah kering berfungsi untuk menghilangkan aroma tengik pada minyak kelapa sehingga membuat minyak kelapa menjadi wangi. Waktu yang diperlukan dalam proses pemasakan kira-kira 2-3 jam. 
5. Setelah beberapa jam santan akan mengeluarkan minyak dan ampas (blondo) akan terpisah.

6. Goreng sampai ampas (blondo) nya kering kecoklatan dan diamkan minyak kelapa sampai dingin, setelah minyak kelapa dingin dapat disaring dengan penyaring untuk memisahkan antara ampas (blondo) dengan minyak kelapa.

\subsection{Analisis Biaya}

Pada usaha pengolahan minyak di Kecamatan Enok biaya tidak tetap terdiri dari bahan baku yaitu kelapa, Tabel 5. Analisis Biaya Produksi Usaha Pengolahan Minyak Kelapa Per Produksi.

\begin{tabular}{clr}
\hline No & \multicolumn{1}{c}{ Biaya } & Jumlah (Rp) \\
\hline 1. & Biaya Tidak Tetap & \\
& Bahan Baku & $23.600,00$ \\
& Bahan Penolong & \\
& $-\quad$ Air & $4.850,00$ \\
- Minyak Tanah & $1.050,00$ \\
- Garam & 200,00 \\
- Cabe Merah Kering & 60,00 \\
- Daun Pandan Wangi & 200,00 \\
- Bahan Bakar & $5.750,00$ \\
Pengemasan & \\
- Plastik & $1.400,00$ \\
- Karet & 210,00 \\
Biaya Tenaga Kerja & $10.030,00$ \\
Biaya Lain-lain & $8.850,00$ \\
Jumlah & $56.200,00$ \\
Biaya Tetap & \\
Penyusutan Alat & $9.662,67$ \\
Jumlah & $9.662,67$ \\
Total Biaya & $65.862,67$ \\
\hline Sian
\end{tabular}

Sumber: Data primer diolah, 2020

Tabel 5 menunjukkan bahwa biaya tidak tetap sebesar Rp. 56.200,00 per produksi, terdiri dari bahan baku sebesar RP. 23.600,00 bahan baku yaitu kelapa, bahan penolong yang terdiri dari air sebesar Rp. 4.850,00, minyak tanah sebesar Rp. 1.050,00 , garam sebesar Rp. 200,00 , cabe merah kering sebesar RP. 60,00, dan daun pandan wangi sebesar Rp. 200,00 , bahan bakar sebesar Rp. 5.750,00 , biaya pengemasan yaitu plastik sebesar $\mathrm{Rp}$. bahan penolong yaitu air, minyak tanah, garam, cabe kering dan daun pandan, bahan bakar, yang terakhir yaitu biaya tenaga kerja dalam keluarga. Sedangkan biaya tetap terdiri dari biaya penyusutan alat yang terdiri dari parang, cungkilan, baskom, saringan, kuali, sendok pengaduk, tungku, panci, ember, gayung, botol dan biaya lain-lain yaitu upah parut kelapa. Rincian biaya produksi yang dikeluarkan pada usaha pengolahan minyak kelapa di Kecamatan Enok dapat dilihat pada tabel 5. 
antara santan dan air. Garam digunakan sebagai perusak kestabilan emulsi. Metode penggaraman dilakukan dengan tujuan untuk pemecahan sistem emulsi santan dengan pengaturan kelarutan protein didalam garam. Protein didalam santan akan larut dengan adanya penambahan garam, akan tetapi pada kondisi tertentu kelarutan protein akan turun seiring dengan peningkatan konsentrasi garam. Dengan penurunan tingkat kelarutan protein diikuti dengan pengikatan molekul-moleku air oleh garam tersebut yang selanjutnya juga terjadi pemisahan antara cairan minyak dengan air (Marlina dkk., 2017).

Penambahan daun padan wangi diberikan pada proses dimana santan dimasak, daun pandan ini berfungsi untuk menghilangkan bau tengik pada minyak dan membuat minyak kelapa menjad wangi. Daun pandan wangi dapat digunakan untuk meningkatkan kualitas minyak kelapa tradisional karena memilki aroma alami dan berfungsi sebagai anti oksidan karena memilki beberapa senyawa seperti flavonoid dan fenolik (Suryani dkk., 2017).

\subsection{Penerimaan dan Keuntungan}

Komposisi penerimaan, keuntungan, dan efisiensi usaha pengolahan minyak kelapa di Kecamatan Enok Kabupaten Indragiri Hilir tersaji pada Tabel 6.

Tabel 6. Penerimaan Usaha Pengolahan Minyak Kelapa di Kecamatan Enok Kabupaten Indragiri Hilir Per Produksi.

\begin{tabular}{cllr}
\hline No & \multicolumn{1}{c}{ Uraian } & \multicolumn{1}{c}{ Satuan } & Jumlah (Rp) \\
\hline 1. & Produksi & Liter & 6,93 \\
2. & Harga jual & Rp/Liter & $19.000,00$ \\
3. & Penerimaan & $\mathrm{Rp}$ & $131.575,00$ \\
4. & Biaya produksi & $\mathrm{Rp}$ & $66.712,67$ \\
5. & Keuntungan $(3-4)$ & $\mathrm{Rp}$ & $64.862,33$ \\
6. & Pendapatan kerja keluarga & $\mathrm{Rp}$ & $84.555,00$ \\
7. & Efisiensi $(3: 4)$ & $\mathrm{Rp}$ & 1,96 \\
\hline
\end{tabular}

Sumber: Data primer diolah, 2020

Tabel 6 menunjukan bahwa penerimaan yang diperoleh rata-rata sebesar Rp. 131.575,00 per produksi dan keuntungan sebesar Rp. 64.862,33 per produksi. Penerimaan diperoleh dari perkalian harga minyak kelapa rata-rata Rp. 19.000,00/liter dengan jumlah produksi minyak kelapa rata-rata yaitu 6,93 liter per produksi.

\section{Pendapatan Kerja Dalam Keluarga}

Pendapatan kerja keluarga merupakan imbalan terhadap bunga harta sendiri, upah tenaga kerja keluarga, dan besarnya penghasilan yang diperoleh. Pendapatan kerja keluarga diperoleh dari pendapatan bersih ditambah dengan upah tenaga kerja dalam keluarga dan penyusutan alat. Besarnya pendapatan tenaga kerja dalam keluarga pada usaha pengolahan minyak kelapa dikarenakan banyaknya jumlah curahan tenaga kerja dalam keluarga yang digunakan pada usaha ini. Pada tabel 6 dapat dilihat bahwa jumlah pendapatan kerja dalam keluarga rata-rata sebesar Rp. $84.555,00$ per produksi.

\section{Efisiensi}

Efisiensi usaha merupakan gambaran layak tidaknya usaha tersebut dilakukan atau diusahakan. Dari tabel 6 dapat dilihat bahwa usaha pengolahan minyak kelapa didaerah penelitian layak untuk diusahakan, hal ini dapat dilihat dari besarnya $\mathrm{R} / \mathrm{C}$ yang didapat yaitu 1,96 ini berarti setiap Rp. 1 biaya yang 
akan dikeluarkan akan menghasilkan pengembalian sebesar Rp. 1,96. Senada dengan penelitian Junianto dkk (2015), efisiensi UKM pengolahan minyak kelapa yang dijual rata-rata sebesar 1,80 yang berarti usaha pengolahan minyak kelapa menguntungkan serta layak untuk di kembangkan.

\subsection{Analisis Nilai Tambah}

Nilai tambah didapat dari besarnya nilai akhir dari produksi usaha minyak kelapa dikurangi dengan besarnya nilai bahan baku dan nilai bahan penolong dan sumbangan input lain. Analisis nilai tambah berguna untuk mengetahui berapa tambahan nilai yang tedapat pada suatu output yang dihasilkan. Nilai tambah usaha pengolahan gula kelapa dapat dilihat pada tabel 7 .

Tabel 7. Analisis Nilai Tambah Usaha Pengolahan Minyak Kelapa.

\begin{tabular}{|c|c|c|c|}
\hline No & Variabel & Perhitungan & $\begin{array}{c}\text { Nilai } \\
\text { Produksi }\end{array}$ \\
\hline & Output, Input dan Harga & & \\
\hline 1 & - Hasil produksi minyak kelapa (liter) & & 6,925 \\
\hline 2 & - Bahan baku kelapa $(\mathrm{kg})$ & & 29,50 \\
\hline 3 & - Tenaga kerja (orang) & & 1,20 \\
\hline 4 & - Faktor konversi & $1 / 2$ & 0,23 \\
\hline 5 & - Koefisien tenaga kerja & $3 / 2$ & 0,04 \\
\hline 6 & - Harga Minyak Kelapa (Rp/liter) & & $19.000,00$ \\
\hline 7 & - Upah tenaga kerja (Rp/orang) & & $12.663,64$ \\
\hline & Penerimaan dan Keuntungan & & \\
\hline 8 & - Harga kelapa $(\mathrm{Rp} / \mathrm{kg})$ & & 800,00 \\
\hline 9 & - Sumbangan input lain $(\mathrm{Rp} / \mathrm{kg})$ & & $2.125,00$ \\
\hline 10 & - Nilai produk minyak kelapa (Rp/kg) & $4 \times 6$ & $4.460,17$ \\
\hline $11 \mathrm{a}$ & - Nilai tambah $(\mathrm{Rp} / \mathrm{kg})$ & $10-9-8$ & $1.535,17$ \\
\hline $11 \mathrm{~b}$ & - Rasio nilai tambah (Rp/kg) & $(11 \mathrm{a} / 10) \times 100 \%$ & 34,42 \\
\hline $12 \mathrm{a}$ & - Imbalan tenaga kerja $(\mathrm{Rp} / \mathrm{kg})$ & $5 \times 7$ & 515,13 \\
\hline $12 b$ & - Pangsa tenaga kerja $(\%)$ & $(12 \mathrm{a} / 11 \mathrm{a}) \times 100 \%$ & 33,56 \\
\hline $13 \mathrm{a}$ & - Keuntungan (Rp/kg) & $11 \mathrm{a}-12 \mathrm{a}$ & $1.020,04$ \\
\hline $13 b$ & - Tingkat keuntungan $(\%)$ & $(13 a / 11 a) \times 100 \%$ & 66,44 \\
\hline
\end{tabular}

Tabel 7 menunjukkan bahwa produksi minyak kelapa per produksi rata-rata adalah 6,925 liter. Untuk menghasilkan produk tersebut diperlukan kelapa masing-masingnya sebanyak 29,50 kg. Dengan demikian konversi minyak kelapa adalah 0,23 yang artinya dari $70 \mathrm{~kg}$ kelapa akan dihasilkan 15,75 liter minyak kelapa. Jumlah tenaga kerja yang digunakan 1,2 orang. Angka koefisien tenaga kerja yang diperoleh adalah 0,04 .
Nilai produk minyak kelapa adalah Rp. 19.000,00 per liter bahan baku (diperoleh dari hasil dari antara faktor konversi dengan harga produknya). Nilai tambah yang diperoleh dari pengolahan 1 liter minyak kelapa adalah sebesar Rp. 1.535,17. Nilai tambah ini di peroleh dari pengurangan nilai produk dengan harga bahan baku dan nilai input lain. Rasio nilai tambah yang diperoleh dari nilai tambah dibagi nilai produksi 
minyak kelapa dikali seratus persen yaitu sebesar 34,42 persen.

Sumbangan tenaga kerja yang diperoleh dari hasil kali antara koefisien tenaga kerja dengan upah tenaga kerja yaitu sebesar 515,13 per kg. Persentase imbalan tenaga kerja terhadap nilai tambahnya diperoleh dari imbalan tenaga kerja dibagi rasio nilai tambah dikali seratus persen yaitu sebesar 33,56 persen. Imbalan terhadap modal dan keuntungan diperoleh dari nilai tambah dikurangi sebesar imbalan tenaga kerja. Keuntungan dari pengolahan minyak kelapa adalah sebesar Rp. 1.020,04 per $\mathrm{kg}$. Tingkat keuntungan diperoleh dari keuntungan dibagi nilai tambah dikali seratus persen yaitu sebesar 66,44 persen.

\section{KESIMPULAN DAN SARAN}

\subsection{Kesimpulan}

1. Biaya total yang diperlukan pada usaha minyak kelapa sebesar Rp. 65.862,00 per produksi, Penerimaan yang diperoleh pada usaha minyak kelapa sebesar Rp. 131.575,00 per produksi dan keuntungan sebesar Rp. 64.862,33 per produksi.

2. Nilai Efisiensi atau R/C yang diperoleh pada usaha minyak kelapa sebesar Rp. 1,96 artinya usahatani minyak kelapa efisien bagi petani di Kecamatan Enok.

3. Nilai tambah pengolahan minyak kelapa sebesar Rp. $1.535,17$ per kg.

\subsection{Saran}

Pengolahan minyak kelapa merupakan alternatif terhadap permasalahan harga kelapa mentah yang fluktuatif. Namun saat ini, usaha tersebut hanya dilakukan secara sederhana dan kapasitas produksi yang kecil sehingga perlu adanya peningkatan dan frekuensi produksi.

\section{DAFTAR PUSTAKA}

Badan Pusat Statistik Kabupaten Indragiri Hilir. 2015. Indragiri Hilir dalam Angka.

Dinas Koperasi dan UMKM Kabupaten Indragiri Hilir. 2017.

Hayami Y. 1987. Agriculture Marketing and Processing in Upland Java: A Prosfectif form A Sunda Village : Bogor

Junianto, R. Hadi, S dan Muwardi, D. 2015. Analisis Usaha Kecil Menengah Pengolahan Minyak Kelapa Rakyat di Kecamatan Enok Kabupaten Indragiri Hilir. JOM, 2 (1) : 1-12.

Kateren, S. 1986. Pengatar Teknologi Minyak dan Lemak Pangan. UI Press. Jakarta.

Marlina, M; Dwi Wijayanti; Ivo Pangesti Y dan Lilis Safitri. 2017. Pembuatan Virgin Ccoconut Oil Dari Kelapa Hibrida Menggunakan Metode Penggaraman Dengan $\mathrm{NaCl}$ dan Garam Dapur. Jurnal Chemurgy. Volume 1 No 2.

Soekartawi. 1995. Analisi Usaha Tani, Universitas Indonesia - Press : Jakarta. 2001

Soekartawi. 2002. Prinsip Dasar Ekonomi Pertanian: Teori Dana Aplikasinya. Raja Grafindo, Jakarta.

Suryani; C.L.S. Tamaroh; A. Ardiyan dan A. Setyowati. 2017. Aktivitas Antioksidan Ekstrak Etanol Daun Pandan (Pandanus amaryllifolius) dan Fraksifarksinya. Jurnal Agritech Vol.37 No 3. 271-279. 